\title{
Onde estão as fronteiras do Brasil?
}

\section{Hervé Thery}

\section{Introdução}

O lugar do Brasil no mundo já mudou, e ainda vai mudar: afirmar que ele é um "país emergente" e uma significativa potência econômica, política e diplomática, é apenas enunciar um fato cada vez mais evidente. Pode-se até argumentar, como faz Théry (2016), que ele é agora um país "emergido" porque já passou as principais etapas de um desenvolvimento duradouro.

Nesta perspectiva, devemos nos perguntar onde estão hoje as suas fronteiras, não no sentido das linhas que delimitam seu território em relação a países contíguos, mas num sentido mais amplo: quem são seus "vizinhos" no plano econômico, social, cultural? A quem ele mais se assemelha, com o quem ele se relaciona? Onde se "situa" ele, no sentido real da palavra?

O conjunto de imagens que segue representa a situação do Brasil no mundo, elas são extraídas, em sua maioria (exceto o primeiro conjunto, sobre comparações) da terceira edição do Atlas do Brasil (Théry \& Mello-Théry, Edusp, 2017). Os mapas foram escolhidos para apresentar o país em vários contextos, econômicos e sociais e são seguidos de comentários voluntariamente breves, já que se supõe que sejam autoexplicativos.

Todos eles foram realizados (pelo menos na sua fase inicial, a arte final sendo sempre realizada no Adobe Illustrator) usando softwares de tratamento estatístico e de cartografia gratuitos ou de baixo custo para estudantes e professores, Philcarto (<http://philcarto.free.fr/>) e Cartes et Données (<http://www.articque.com/geocampus/>).

\section{Comparações}

Os dados da tabela 1 relacionam cada um dos 26 estados da União e o Distrito Federal com um país estrangeiro quanto a três variáveis: área (em milhares de quilômetros quadrados), população (em milhões de habitantes); e o Índice de Desenvolvimento Humano, ou IDH, calculado pelo PNUD na escala dos países e recalculado pela mesma agência para os Estados brasileiros.

A tabela se lê linha por linha, como segue: Rondônia tem uma área comparável à do país $\mathrm{X}$, uma população comparável à do país e Y um IDH comparável à do país $Z$. A simples aproximação das comparações com países muito diferentes entre si já dá pistas sobre a dissimilaridade das situações entre estados enormes e pouco povoados - especialmente na Amazônia - outros povoados, mas pobres - no Nordeste - e ainda outros que têm atingido, com relativamente altos níveis populacionais, níveis de vida próximos daqueles de alguns países europeus.

Para facilitar a comparação visual destes dados globais, foram utilizados mapas que associam estados brasileiros e os países do mundo. A figura 1

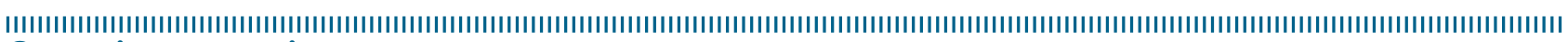
Como citar este artigo:

THERY, Hervé. “Onde estão as fronteiras do Brasil?”. In: RÜCKERT, A. A.; SILVA, A. C. P. da; SILVA, G. de V. (Orgs.). Geografia Política, Geopolítica e Gestão do Território: integração sul-americana e regiões periféricas. Porto Alegre: Editora Letra1, 2018, p. 234-249 DOI 10.21507/9788563800367-14 
Tabela 1. Países estrangeiros e estados brasileiros, três variáveis.

\begin{tabular}{|c|c|c|c|c|c|c|c|c|c|}
\hline \multirow{2}{*}{$\begin{array}{l}\text { Estado } \\
\text { Rondônia }\end{array}$} & \multicolumn{2}{|c|}{$\begin{array}{l}\text { Área } \\
\left(\mathbf{1 0 0 0 k m ^ { 2 } )}\right.\end{array}$} & \multicolumn{4}{|c|}{$\begin{array}{l}\text { População } \\
\text { (Milhões de habitantes ) }\end{array}$} & \multicolumn{3}{|c|}{ IDH 2010} \\
\hline & 239 & Uganda & 241 & 1,6 & Gabão & 1,6 & 0,69 & Samoa & 0,694 \\
\hline Acre & 159 & Senegal & 197 & 0,7 & Guiana & 0,8 & 0,663 & El Salvador & 0,662 \\
\hline Amazonas & 1.578 & Iran & 1.648 & 3,5 & Uruguai & 3,4 & 0,674 & Gabão & 0,674 \\
\hline Roraima & 225 & Guiana & 215 & 0,5 & Malta & 0,4 & 0,707 & Tonga & 0,705 \\
\hline Para & 1.253 & Angola & 1.247 & 7,6 & Bulgaria & 7,4 & 0,646 & Iraque & 0,642 \\
\hline Amapá & 143 & Grécia & 132 & 0,7 & $\begin{array}{l}\text { Guiné } \\
\text { Equatorial }\end{array}$ & 0,7 & 0,708 & Suriname & 0,705 \\
\hline Tocantins & 278 & Gabão & 268 & 1,4 & Estônia & 1,3 & 0,699 & Turcomenistão & 0,698 \\
\hline Maranhão & 333 & Malásia & 330 & 6,6 & Papuásia & 6,6 & 0,639 & Guiana & 0,638 \\
\hline Piauí & 252 & Guiné & 246 & 3,1 & Armenia & 3,3 & 0,646 & Vietnam & 0,638 \\
\hline Ceará & 146 & Bangladesh & 144 & 8,5 & Áustria & 8,4 & 0,682 & Egito & 0,682 \\
\hline Rio Grande do Norte & 53 & Eslováquia & 49 & 3,2 & Moldávia & 3,6 & 0,684 & Indonesia & 0,684 \\
\hline Paraíba & 57 & Croácia & 57 & 3,8 & Bosnia & 3,8 & 0,658 & África do & 0,658 \\
\hline Pernambuco & 99 & Hungria & 93 & 8,8 & Honduras & 8,4 & 0,673 & Bolívia & 0,667 \\
\hline Alagoas & 28 & Ruanda & 26 & 3,1 & Lituânia & 2,9 & 0,631 & Guatemala & 0,628 \\
\hline Sergipe & 22 & Belize & 23 & 2,1 & Letônia & 2,0 & 0,665 & Moldova & 0,663 \\
\hline Bahia & 567 & Quênia & 580 & 14,0 & Camboja & 14,7 & 0,66 & Filipinas & 0,660 \\
\hline Minas Gerais & 588 & Botswana & 582 & 19,6 & Romênia & 19,8 & 0,731 & Bósnia & 0,731 \\
\hline Espírito Santo & 46 & Estônia & 45 & 3,5 & Mauritania & 3,5 & 0,74 & Peru & 0,737 \\
\hline Rio de Janeiro & 44 & Dinamarca & 43 & 16,0 & Equador & 15,9 & 0,761 & Costa Rica & 0,763 \\
\hline São Paulo & 249 & Romênia & 238 & 41,3 & Argentine & 42,7 & 0,783 & Romênia & 0,785 \\
\hline Paraná & 200 & Quirguistão & 200 & 10,4 & Portugal & 10,5 & 0,749 & Iran & 0,749 \\
\hline Santa Catarina & 95 & Jordânia & 89 & 6,2 & Paraguai & 6,7 & 0,774 & Malásia & 0,773 \\
\hline Rio Grande do Sul & 282 & Equador & 284 & 10,7 & Guiné & 10,6 & 0,746 & Azerbaijão & 0,747 \\
\hline Mato Grosso do Sul & 358 & Alemanha & 357 & 2,4 & Botswana & 2,2 & 0,729 & Armênia & 0,730 \\
\hline Mato Grosso & 907 & Nigéria & 924 & 3,0 & Albânia & 2,9 & 0,725 & Fiji & 0,724 \\
\hline Goiás & 341 & Finlândia & 338 & 6,0 & Libia & 6,0 & 0,735 & Ucrânia & 0,734 \\
\hline Distrito Federal & 6 & Brunei & 6 & 2,6 & Jamaica & 2,7 & 0,824 & Chile & 0,822 \\
\hline Total / média & 8.544 & & 8.601 & 191 & & 193 & 0.705 & & 0,703 \\
\hline
\end{tabular}

Figura 1. População dos países e Estados.

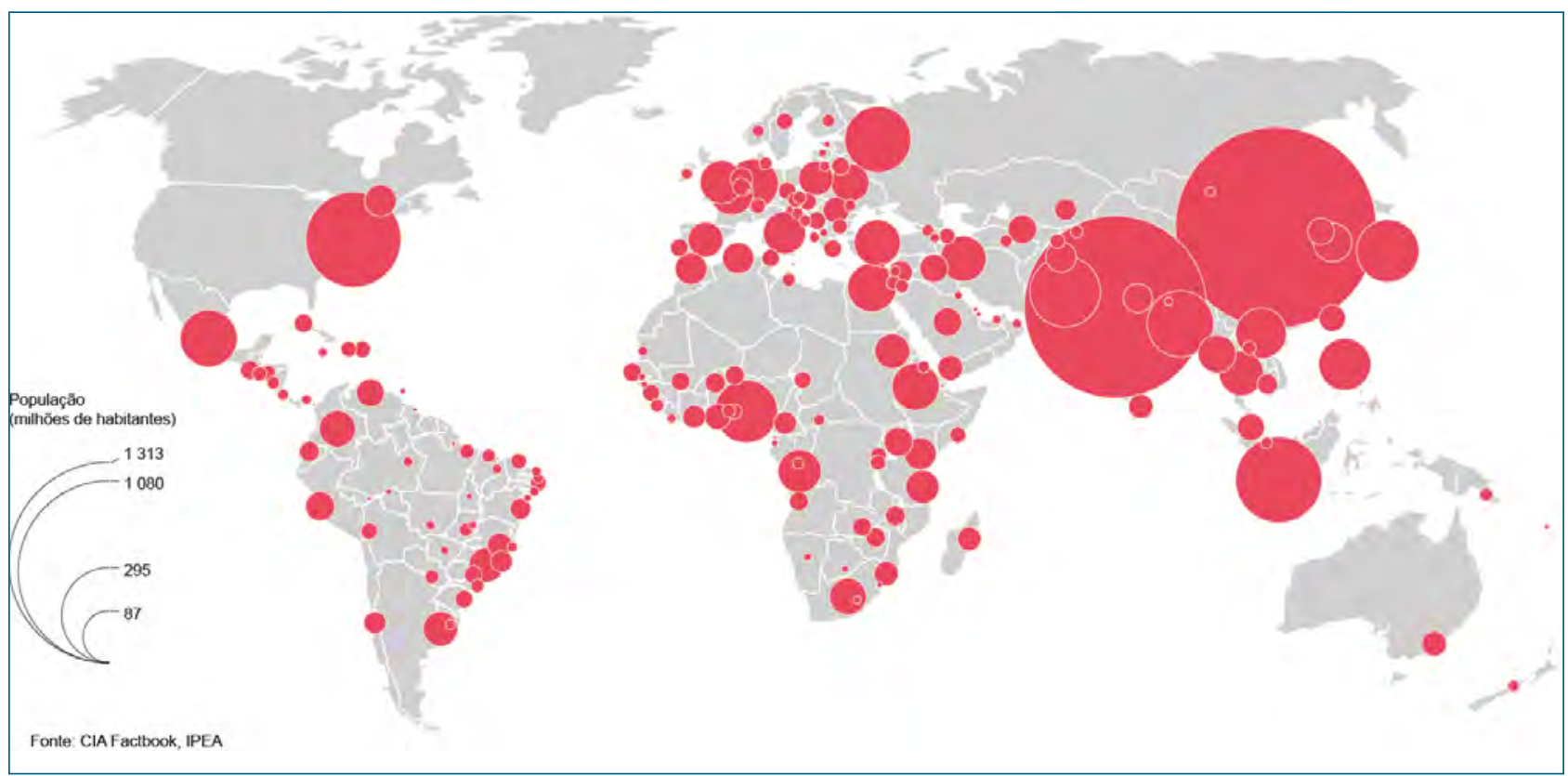


mostra que os estados do Sudeste e Sul do Brasil têm um peso demográfico comparável ao de muitos países, iniciando por seus vizinhos sulamericanos; o estado de São Paulo e Argentina estando em situações similares. No entanto, a população dos estados da Amazônia é reduzida em relação aos seus vastos tamanhos.

A figura 2, que combina área e população para o cálculo da densidade, também destaca os estados de São Paulo e Rio de Janeiro, tão alta quanto alguns paises europeus (e maior do que a da França), enquanto os estados da Amazônia têm densidades baixas, próximas daquelas do Sahel e do Saara, do Canadá ou da Austrália.

Na figura 3, o mapa do IDH, o Brasil também mostra partes - no Sul-Sudeste e no CentroOeste - com pontuações comparáveis às da Europa Oriental, enquanto o Norte e Nordeste obtêm, nos melhores casos, aquelas próximas às da África do Norte ou do Sul, ou do Sudeste Asiático.

Para situar melhor as áreas dos estados brasileiros, usou-se o artifício de sobrepor seu contorno aos limites de países de tamanho comparável. Nem todos os ajustes são perfeitos, pois, os países podem ter a mesma área de um estado brasileiro, mas não a mesma forma, mas, por vezes, a forma está próxima, e a comparação é tanto mais surpreendente, como nos casos Nigéria / Mato Grosso, Angola / Pará, Mato Grosso do Sul / Alemanha, Botswana / Minas Gerais e Romênia / São Paulo (no último caso, inclinando ligeiramente o mapa da Romênia).

Finalmente, para juntar os três dados e tentar um tratamento visual similar à Tabela 1 , foram superpostos a um mapa do Brasil o nome de um país equivalente em tamanho a cada estado (com nome em preto), representando como um gráfico de barras a população do seu equivalente demográfico e indicando o seu equivalente em IDH. O mapa confirma o que aparecia na última linha da tabela, a área total do Brasil é muito próxima do total desses 28 países - alguns dos quais não são pequenos - e esse tipo de Frankenstein cartográfico reconstitui razoavelmente o mosaico brasileiro.

Pode-se assim "viajar" pelo país, lendo o três nomes de países associados a cada estado, para medir a diversidade de situações. Ao limitar-nos a dois exemplos, podemos constatar que São Paulo tem o tamanho e o IDH da Romênia com a população da Argentina, enquanto Brasília tem o tamanho do Sultanato de Brunei, a população da Jamaica e o IDH do Chile. Obviamente, tais especificidades continuarão a alimentar as piadas que os brasileiros fazem sobre a sua capital.

\section{Comércio exterior}

Uma marca da transformação da posição do Brasil no panorama mundial é o comercio exterior. Por muito tempo a exportação de minérios e de produtos agrícolas foi sua base econômica, e continua sendo um dos principais exportadores mundiais de alguns minérios (minério de ferro em particular) e alguns produtos agrícolas: ainda é o primeiro exportador mundial de café, de açúcar, de suco de laranja e se classifica entre os primeiros para a soja.

Porém, hoje tem também uma posição de destaque no ramo dos bens manufaturados, e o seu parque industrial, o mais completo do hemisfério Sul, atingiu um nível suficiente para competir com os maiores do planeta. Em um domínio sensível como a construção aeronáutica, o pais se insere na elite mundial, rivalizando com o grupo canadense Bombardier pelo terceiro lugar mundial, atrás dos gigantes Airbus e Boeing, dominando tecnologias complexas. Pode-se citar outros ramos, como o da engenharia civil, em que o Brasil detém experiência preciosa, adquirida no vasto canteiro de obras que foi e continua sendo o País, usada também na reconstrução de países arrasados por guerras, como foi o caso da Angola após a sua longa guerra civil, ou no Iraque após a guerra contra o Irã.

Ademais, o novo papel internacional do Brasil não é somente comercial e industrial, é também cultural. Gigante do mundo lusófono, o Brasil é o único país de língua portuguesa realmente presente no mercado mundial de comunicação. A sua principal rede de televisão, a Globo, carrochefe de um potente grupo de imprensa, está entre as primeiras do mundo e vende suas criações audiovisuais, especialmente novelas, a numerosas televisões estrangeiras. Pode-se ver aí o símbolo 
Figura 2. Densidade populacional dos países e estados.

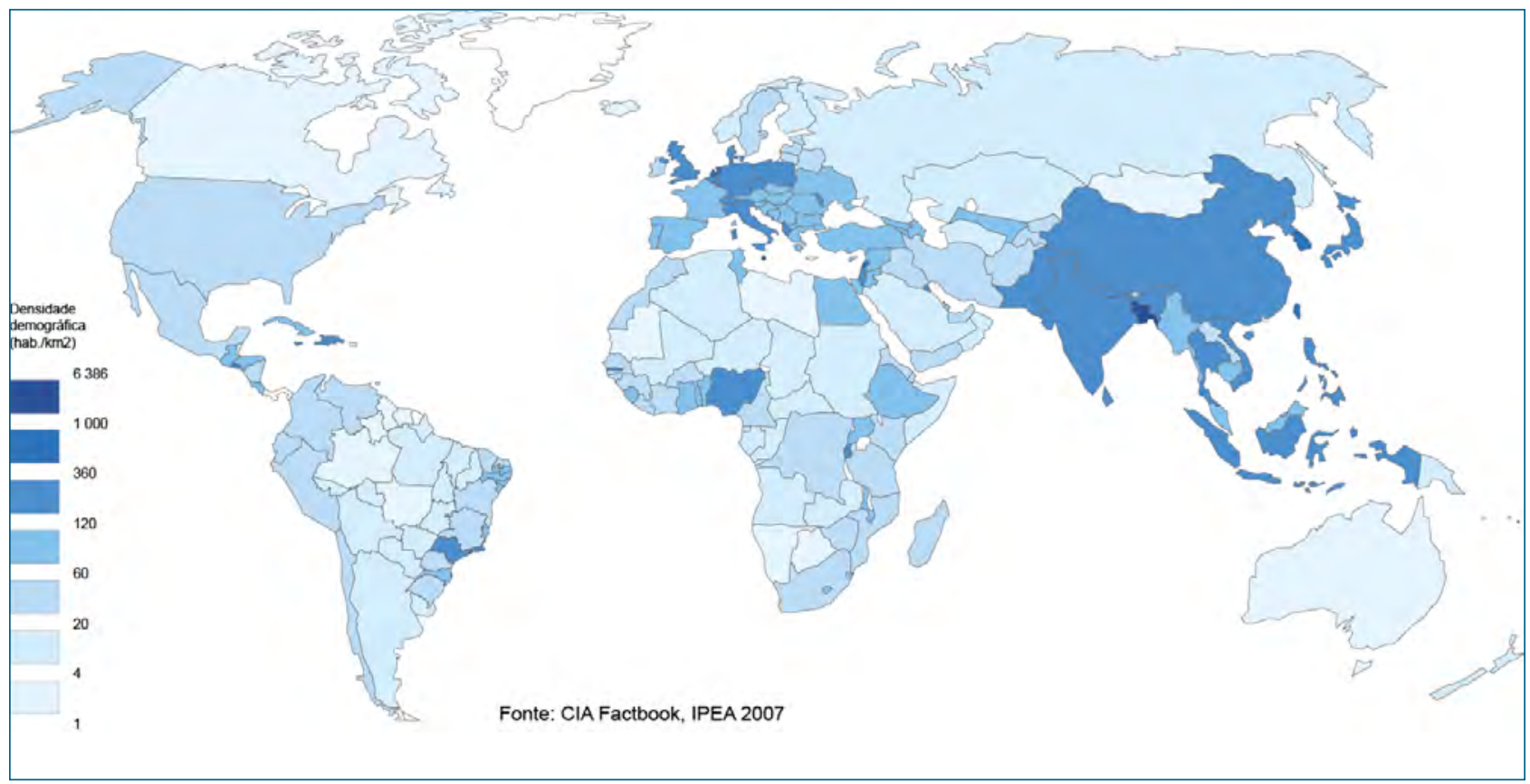

Figura 3. IDH dos países e estados.

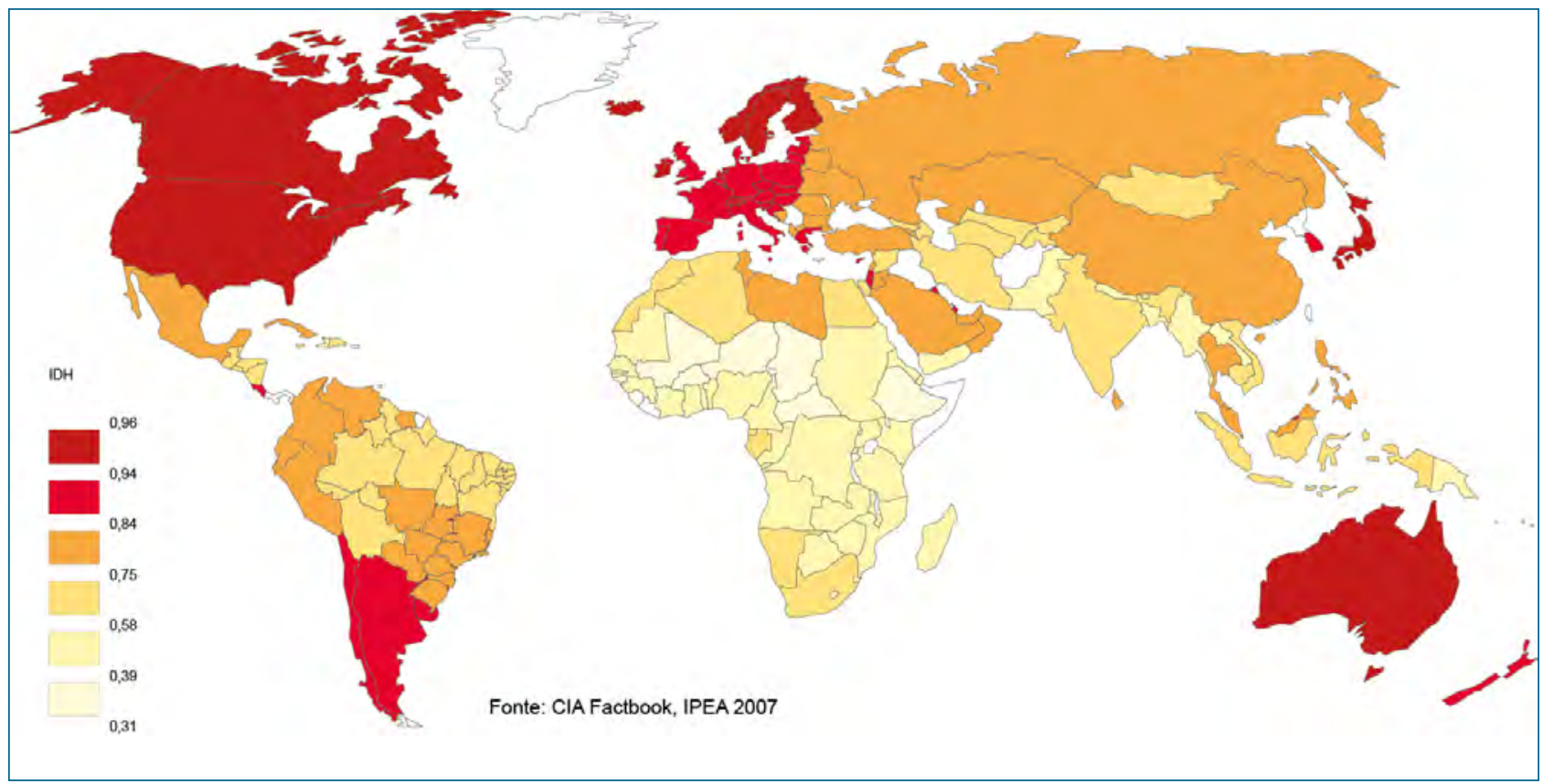

da nova postura brasileira na cena mundial, um verdadeiro soft power que reforça o seu peso comercial e diplomático.

Observando a composição e a orientação de suas exportações e importações, pode-se ver até que ponto se alterou a sua situação no comércio mundial. O fato marcante é o aumento das exportações para a Ásia e América Latina, enquanto a percentagem daquelas que vão para a União Europeia e os Estados Unidos diminui, pelo menos, em proporção. Os principais parceiros ainda são os vizinhos do Mercosul, principalmente Argentina, os Estados Unidos, a Europa, e cada vez mais a China, cujo peso ainda era muito limitado há dez anos. Ela agora ultrapassou o Japão como principal parceiro asiático por meio 
Figura 4. Estados e países de área equivalente.

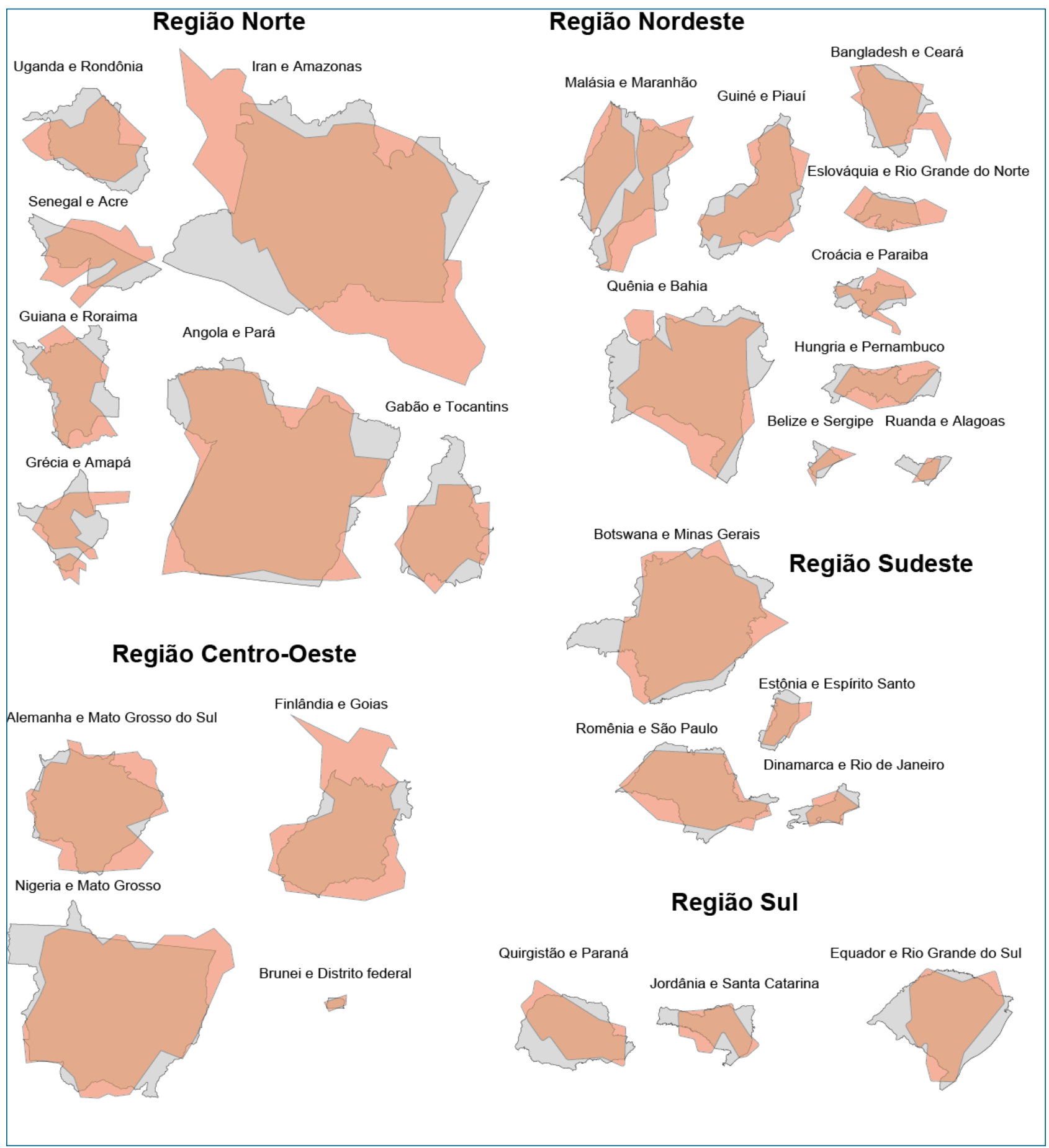

de suas compras maciças de minério de ferro, soja, carne e açúcar, em troca de uma multidão de produtos manufaturados, desde os mais banais (têxteis baratos), até os mais sofisticados (eletrodomésticos e informática).

\section{Fluxos marítimos e aéreos}

O transporte marítimo, pelo qual passa a maior parte do comércio exterior do Brasil, tem um perfil diferente na exportação e na importação. O que 
Figura 5. Países e estados brasileiros, as equivalências

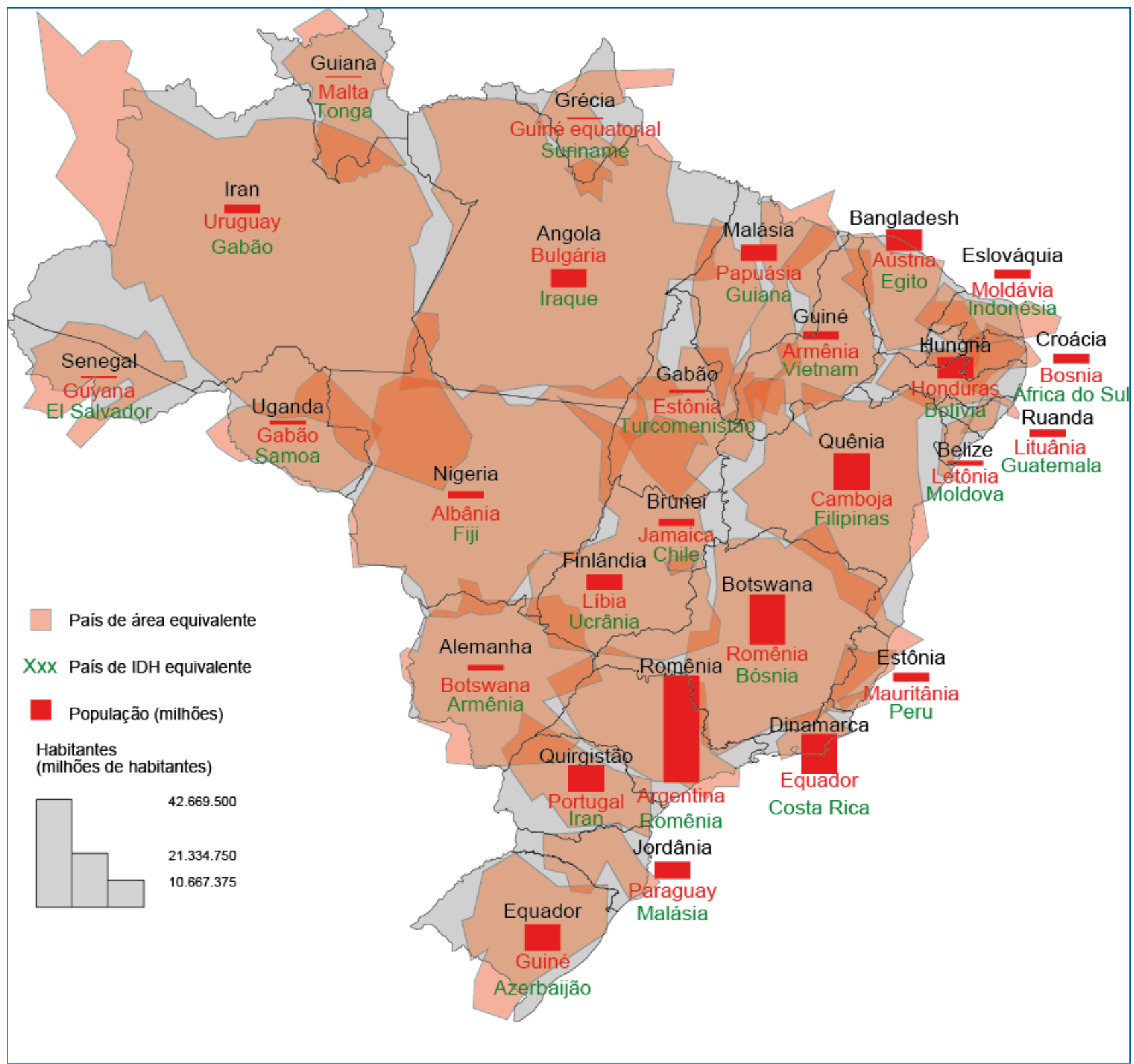

é embarcado nos portos brasileiros, como granel sólido, vai principalmente para a China, grande compradora de minério de ferro e de soja brasileira, através do Canal do Panamá. As exportações para os EUA e a Europa são mais limitadas exceto, de novo, a soja e o minério de ferro, que transitam principalmente pelo porto de Roterdã.

Nas exportações e importações por via aérea as tonelagens são evidentemente menores, mas os valores não são muito inferiores aos das importações marítimas, porque são produtos de alto valor, os únicos que podem suportar o custo elevado de transporte aéreo. O frete aéreo para o Brasil vem principalmente dos Estados Unidos e transportado por empresas brasileiras, enquanto as empresas estrangeiras também importam produtos da Europa. Na exportação de carga para os Estados Unidos dominam as empresas estrangeiras enquanto as empresas brasileiras dominam nas exportações para a Europa.

Como os fluxos de comércio já deixavam vislumbrar, os intercâmbios do Brasil com o resto do mundo favorecem alguns países e deixam outros de lado. Uma primeira abordagem é dada 
Figura 6. Comercio exterior por blocos.

\section{Variação da proporção do bloco no comercio exterior brasileiro}

\author{
aumento \\ : - - _ diminuição
}
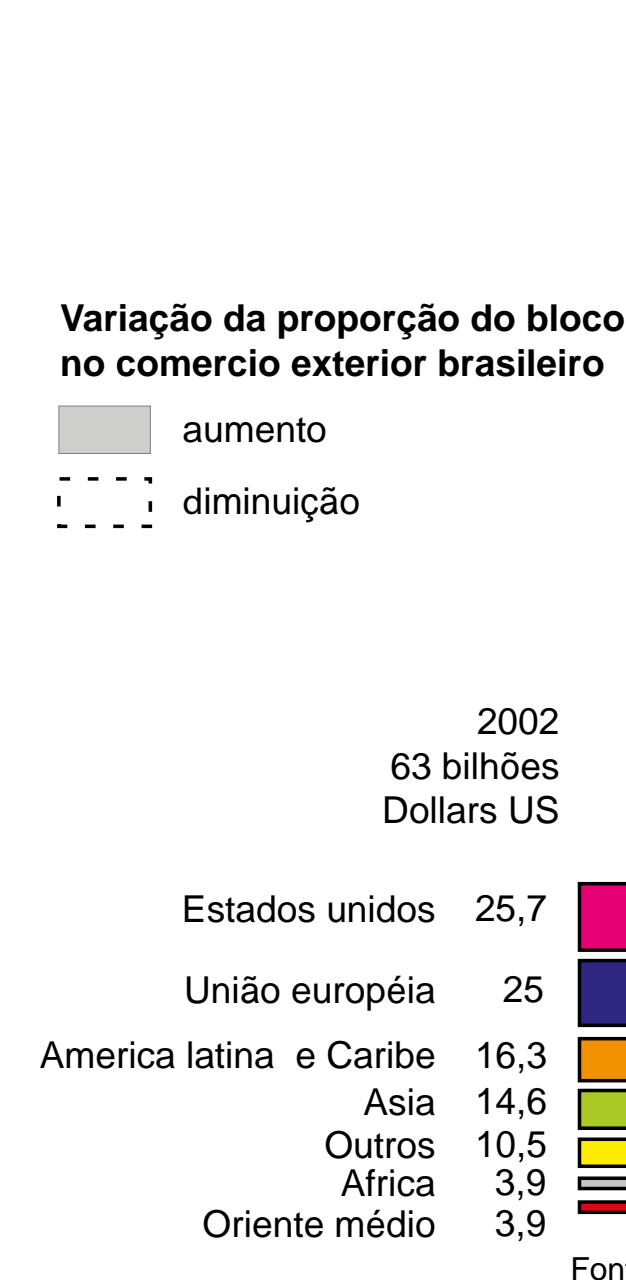

CHT/NAMT 2014

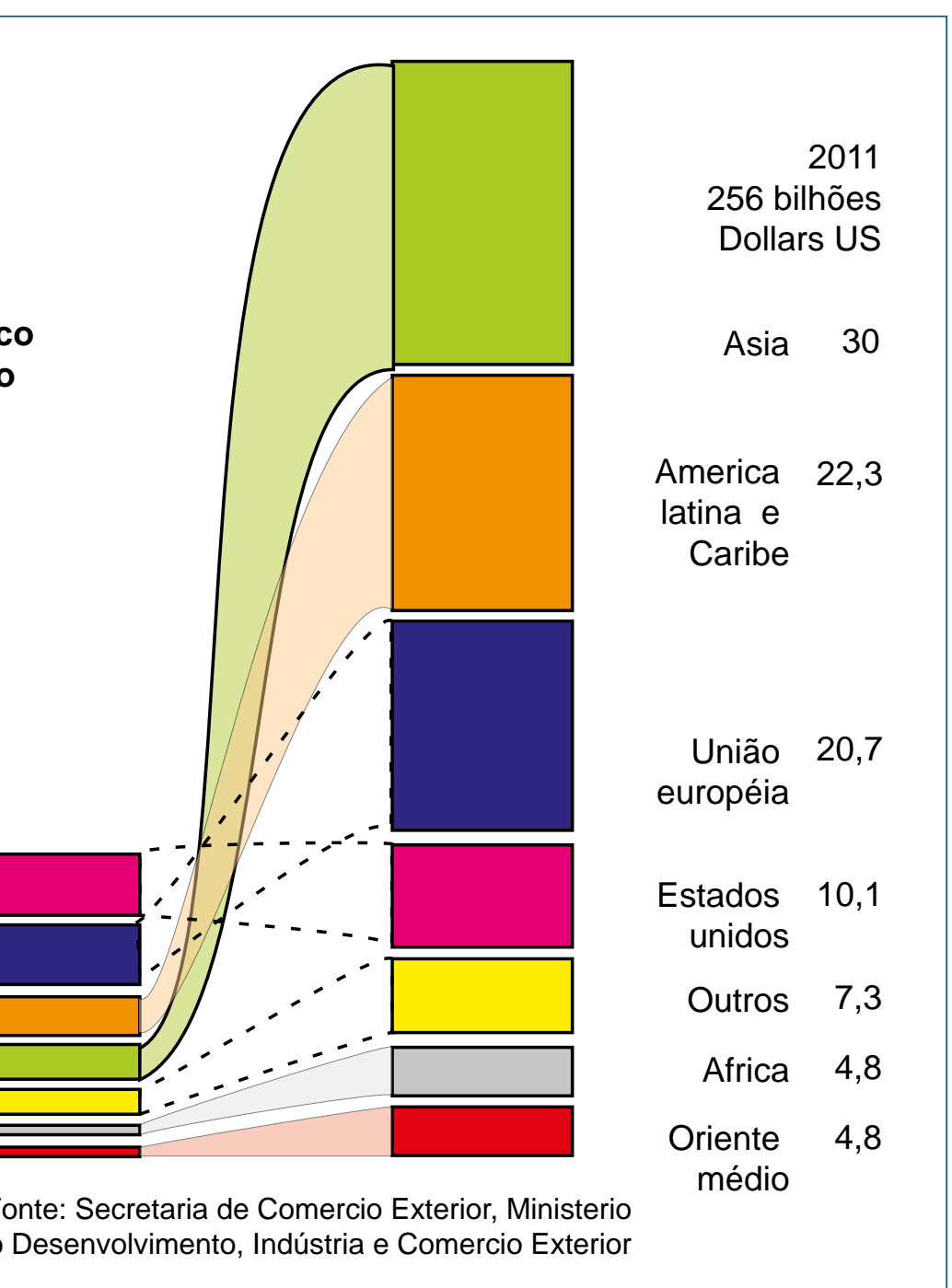

America 22,3 atina e Caribe

União 20,7

stados 10,1

Outros 7,3

Africa 4,8

riente $\quad 4,8$

médio pelas linhas aéreas para as quais as empresas aéreas julgam que o fluxo de passageiros será suficientemente rentável, e as fecham rapidamente se não for o caso. A escolha de destinos servidos a partir do Brasil ou das cidades a partir das quais se é possível embarcar para o Brasil é, portanto, um bom indicador do estado das relações entre o país e tal ou qual cidade no mundo.

O mapa das redes aéreas internacionais com ponto de partida no Brasil ou com destino no Brasil mostra as escolhas feitas pelas companhias brasileiras e estrangeiras. As primeiras transportam passageiros principalmente para a Argentina e os Estados Unidos, as segundas adicionam linhas para a Europa, Golfo Pérsico e
Ásia, com menor magnitude. Os únicos destinos africanos de importância resumem-se a Angola e África do Sul.

\section{Turismo e diplomacia}

O turismo é outro bom indicador da atração de um país, porque quem paga para visitá-lo afirma concretamente o seu interesse por ele. Se os encantos turísticos das praias do Sul atraem naturalmente em primeiro lugar os vizinhos argentinos, uruguaios e paraguaios, o Rio de Janeiro, Salvador ou as cataratas do Iguaçu atraem muitos visitantes europeus e norte-americanos. Distinguir o modo de transporte permite fazer a 
Figura 7. Transporte marítimo.

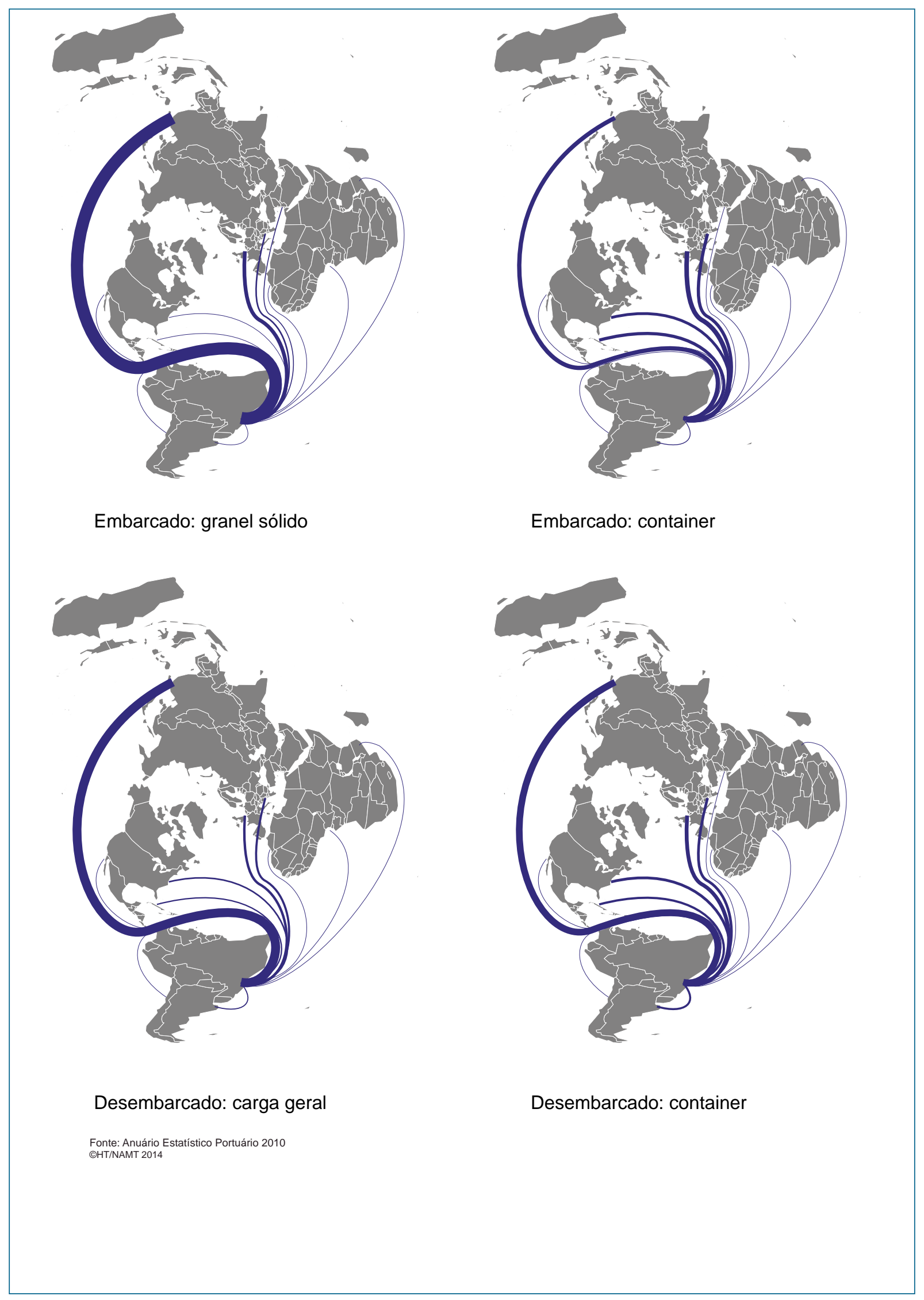


Figura 8. Frete aéreo

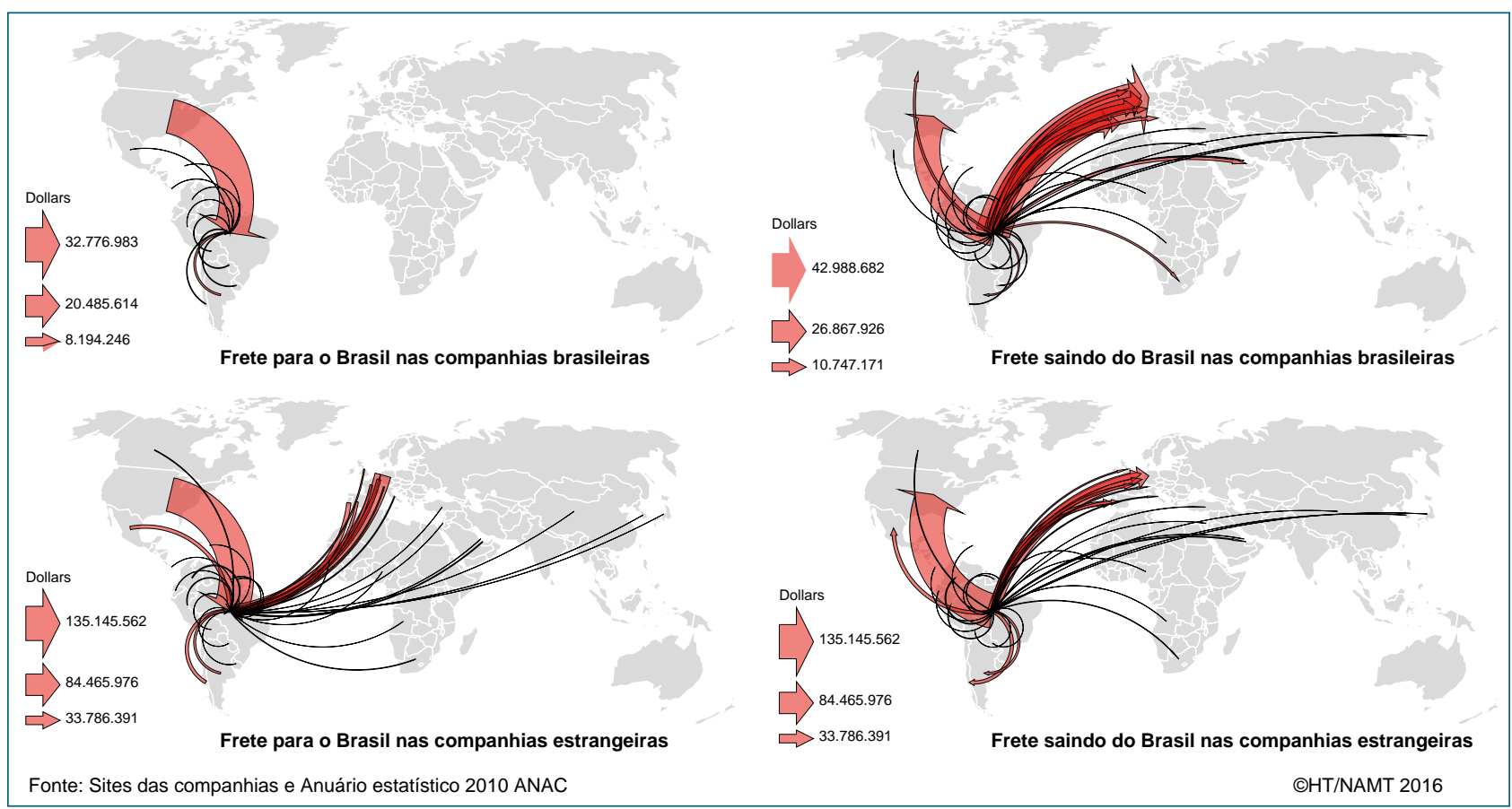

Figura 9. Fluxos aéreos de passageiros

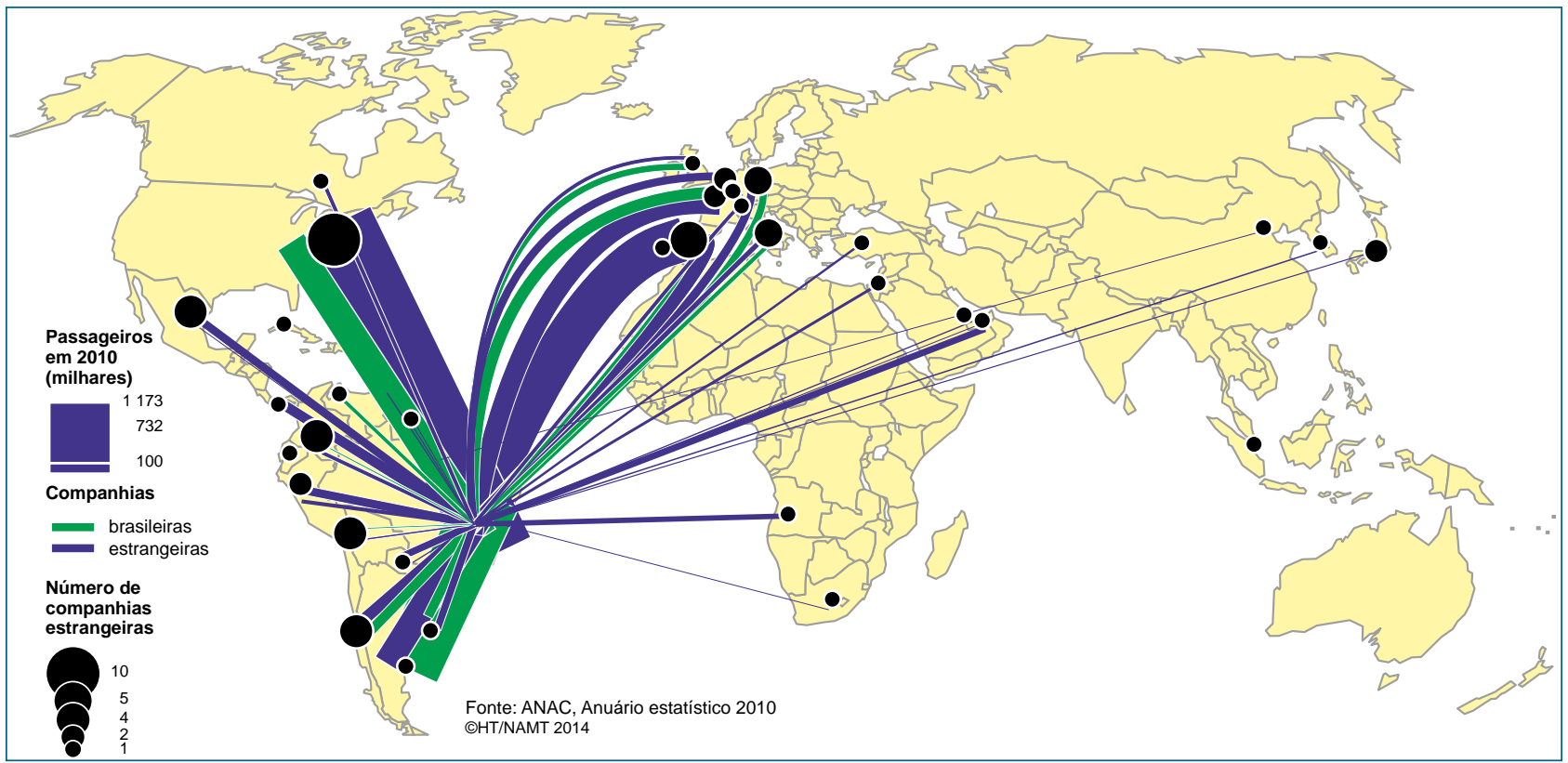

diferença entre os vizinhos imediatos, que chegam por via terrestre, e os turistas que vem de longe por via aérea, sobretudo, norte-americanos e europeus. Navios de cruzeiro são privilegiados por quem quer conhecer praias e paisagens costeiras, mantendose no conforto e na segurança de sua embarcação. Essa atividade turística constitui o setor que mais rapidamente se desenvolve, porque seus organizadores encontram no Brasil uma alternativa ao Caribe, já bastante saturado. É uma nova ocasião de desenvolver um setor ainda muito aquém dos seus potenciais, já que o País recebeu 6,6 milhões de turistas estrangeiros em 2016, enquanto 83 milhões visitavam a França, o país mais procurado.

As relações diplomáticas são outro indicador das relações entre o Brasil e o resto do mundo. 
Figura 10. Turismo no Brasil e no mundo

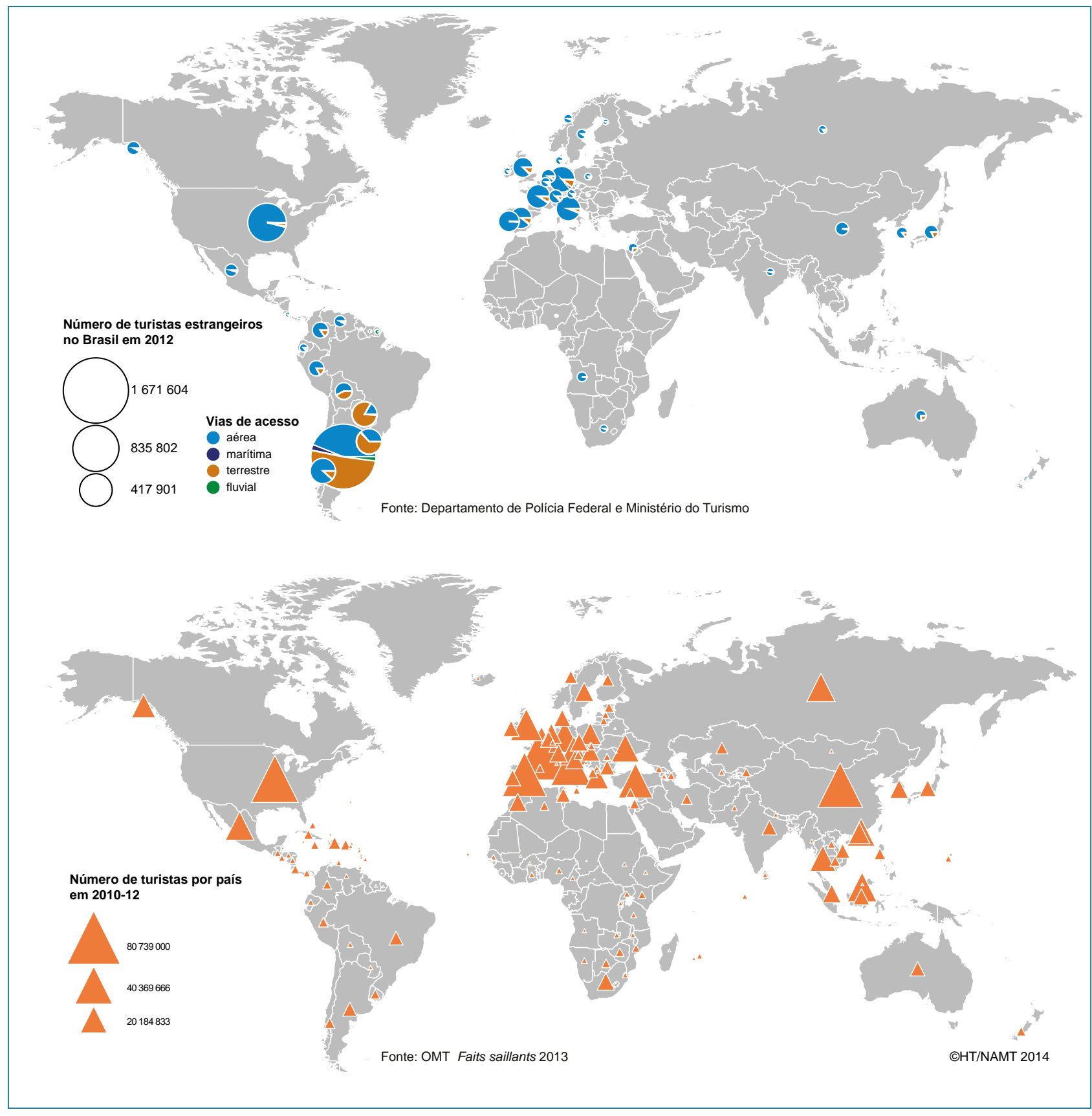

A importância do país pode ser avaliada pelo número de países que têm uma embaixada em seu território: quase todos têm representações diplomáticas no Brasil, com exceção de alguns países da África central e oriental, e da Ásia central. Pode-se questionar a necessidade de uma embaixada no Brasil de alguns países com os quais ele tem pouquíssimos contatos, mas é evidente que a presença de muitas representações é a marca de um grande interesse da comunidade internacional.

No sentido inverso, quais são os países onde o Brasil tem uma representação diplomática? Sua rede de embaixadas e consulados é densa, cobrindo o mundo inteiro, à exceção de alguns países da África central e oriental. Contudo certos parceiros são obviamente mais importantes, pois eles dispõem de consulados gerais (em grandes cidades fora da capital), de consulados (Cidade do Cabo e Caiena) ou de delegações junto a 
Figura 11. Diplomacias

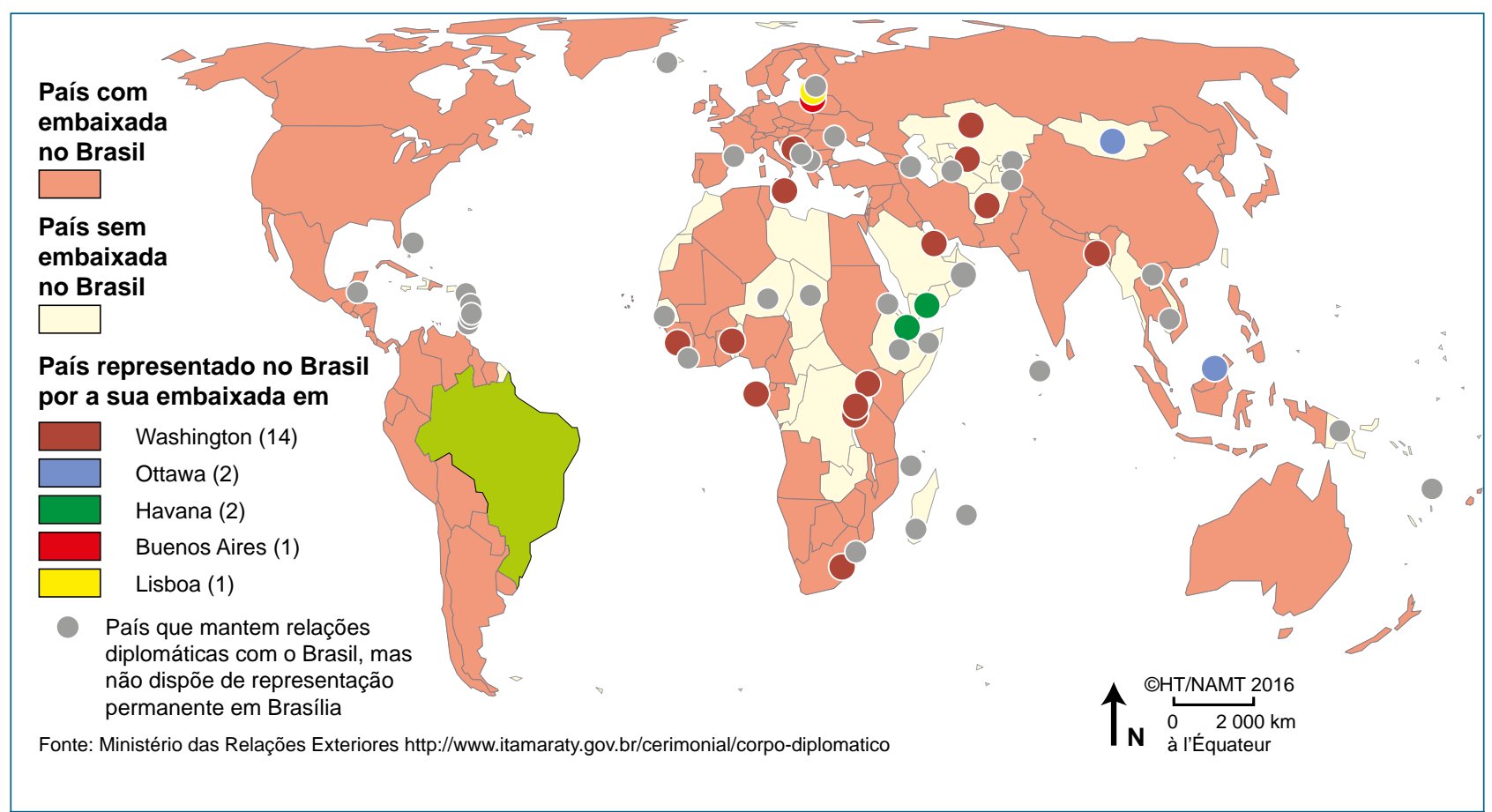

Embaixadas Consulados

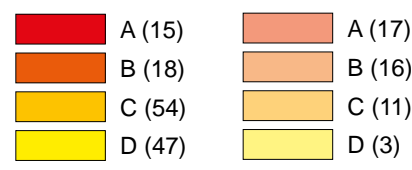

Número de funcionários (2) $\frac{63}{26}$

Fonte: Ministerio das Relações Exteriores

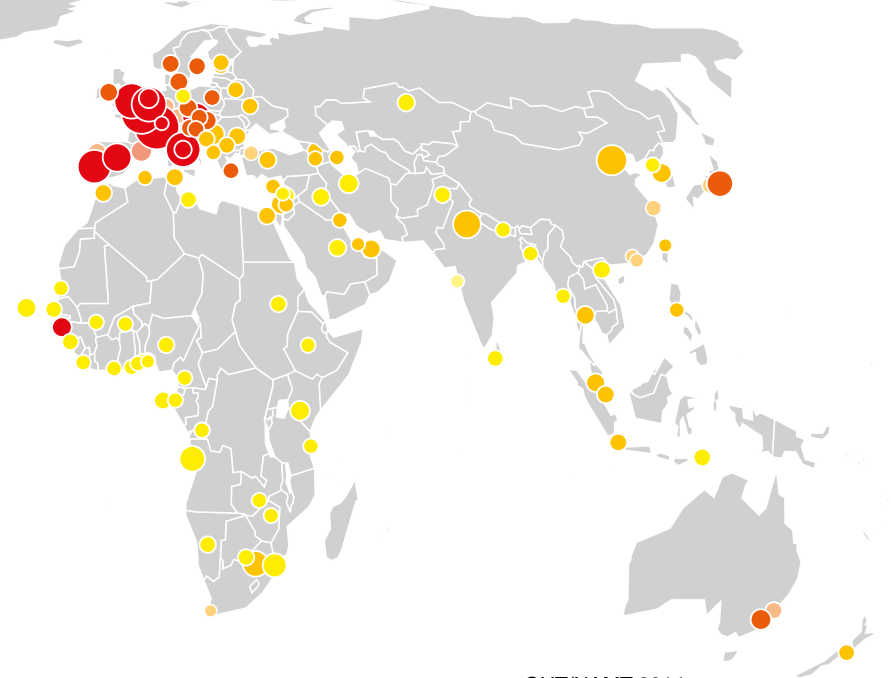

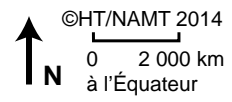

organismos internacionais. É o caso dos Estados Unidos, de alguns grandes países europeus, da China e do Japão e de países vizinhos, onde existem, frequentemente, vice-consulados, que tratam principalmente de vistos.

Muitas novas embaixadas foram criadas no período dos dois mandatos de Luiz Inácio Lula da Silva (2003-2010), particularmente na África, como parte da ambiciosa política africana lançada pelo presidente, que queria mudar radicalmente o posicionamento geopolítico do Brasil e torná-lo um líder do Terceiro Mundo.

Como todas essas representações não tem a mesma importância diplomática, nem o mesmo prestígio, o Ministério das Relações Exteriores as classificou em três categorias, para fins de gestão da carreira dos seus diplomatas, às quais eles podem postular de acordo com regras precisas. Os postos de tipo "A" são os mais prestigiados, pois estão situados nos Estados Unidos ou na 
Europa central. São aqueles apelidados, na gíria diplomática, de "circuito Elizabeth Arden", adquirido do nome dessa sofisticada marca de cosméticos. Os postos "B" são a segunda escolha: Canadá, Europa periférica, Austrália, grandes países asiáticos e latino-americanos, e a África do Sul. Os postos “C” e "D", aqueles de início de carreira ou que são pedidos quando não se tem escolha nas categorias mais desejadas, são os da África, do Oriente Médio, e os não classificados anteriormente na Ásia e na América Latina.

\section{Universidades}

A classificação de universidades mundiais mais conhecida é a ARWU, Academic Ranking of World Universities (dita "de Xangai"), feita pelo Institute of Higher Education da Shanghai Jiao Tong University. O grupo publica anualmente, desde junho de 2003, a sua classificação na web, que analisa todas as Universidades cujos ex-alunos ou professores ganharam um prêmio Nobel, uma medalha Fields ou tiveram artigos publicados na Nature ou Science, cujos pesquisadores figuram entre os mais citados em um determinado campo científico, bem como aqueles que possuem um número significativo de artigos indexados pelo Science Citation Index-Expanded (SCIE) ou Social Science Citation Index (SSCI). Ou seja, no total, mais de mil estabelecimentos, dos quais apenas os 500 primeiros são citados na lista publicada.

Na classificação ARWU, aos pontos obtidos para cada indicador são aplicados os coeficientes abaixo, para se chegar à nota final de cada estabelecimento.

A concentração das 500 Universidades classificadas pelo ARWU em algumas regiões do mundo é de tal grandeza que foi necessário, na figura 12, acrescentar ao mapa-múndi três zooms para detalhar a situação dos Estados Unidos, da Europa e do Japão. Dentro dos Estados Unidos distingue-se claramente um bloco compacto que vai da Nova Inglaterra aos Grandes Lagos, seguido pela Califórnia e - em menor escala - a pelo Texas e a Flórida. Na Europa a concentração das principais universidades reconstitui praticamente a "dorsal europeia" do norte da Inglaterra à Lombardia. No Japão encontra-se a terceira grande megalópole mundial, cuja predominância é assim também confirmada pela geografia das grandes universidades mundiais.

Se escolhas gráficas um pouco diferentes tivessem juntado o Canadá aos Estados Unidos e a Europa do Norte ao resto da União Europeia, o corpo principal do mapa-múndi apareceria quase vazio: nele se encontrariam apenas alguns estabelecimentos latino-americanos (nas cidades do México, São Paulo e Buenos Aires), as Universidades australianas e chinesas, uma na Índia, uma em Cingapura e uma única universidade africana, na Cidade do Cabo.

Mesmo que algumas universidades brasileiras (USP, Unesp, UFRJ, UFMG) tenham se inserido na elite definida pela classificação Arwu, não pode se contentar com esta única abordagem, que aliás foi duramente criticada por ser muito centrada na publicação de artigos em revistas anglófonas. Para isso, foi utilizado uma análise de cluster das instituições (universidades e escolas) presentes em quatro rankings de referência, ou seja, de 96 instituições. Fazer parte desta curta lista já é um critério, uma vez que é necessário um reconhecimento da sua produção científica (Arwu), sua capacidade de produzir líderes de

\begin{tabular}{|c|c|c|c|}
\hline Critérios & Indicador & Código & Peso \\
\hline Qualidade da educação & Ex-alunos com medalhas Fields e prêmios Nobel & Alumi & $10 \%$ \\
\hline \multirow{2}{*}{ Qualidade do corpo docente } & Funcionários com medalhas Fields e prêmios Nobel & Award & $20 \%$ \\
\hline & Pesquisadores mais citados em 21 campos disciplinares & $\mathrm{HiCi}$ & $20 \%$ \\
\hline \multirow{2}{*}{ Resultados das pesquisas } & Artigos publicados em Nature e Science* & $\mathrm{N} \& S$ & $20 \%$ \\
\hline & Artigos citados em Science Citation Index-expanded, e Social Science Citation Index & SCI & $20 \%$ \\
\hline Tamanho do estabelecimento & Resultados dos outros índices divididos pelo número de funcionários do estabelecimento & Size & $10 \%$ \\
\hline
\end{tabular}

* Para estabelecimentos especializados nas ciências humanas e as ciências sociais tais como o London School of Economics, o critério "artigos publicados em Nature e Science" não é considerado, e o peso do mesmo é afetado a outros indicadores 
Figura 12. Classificação de universidades

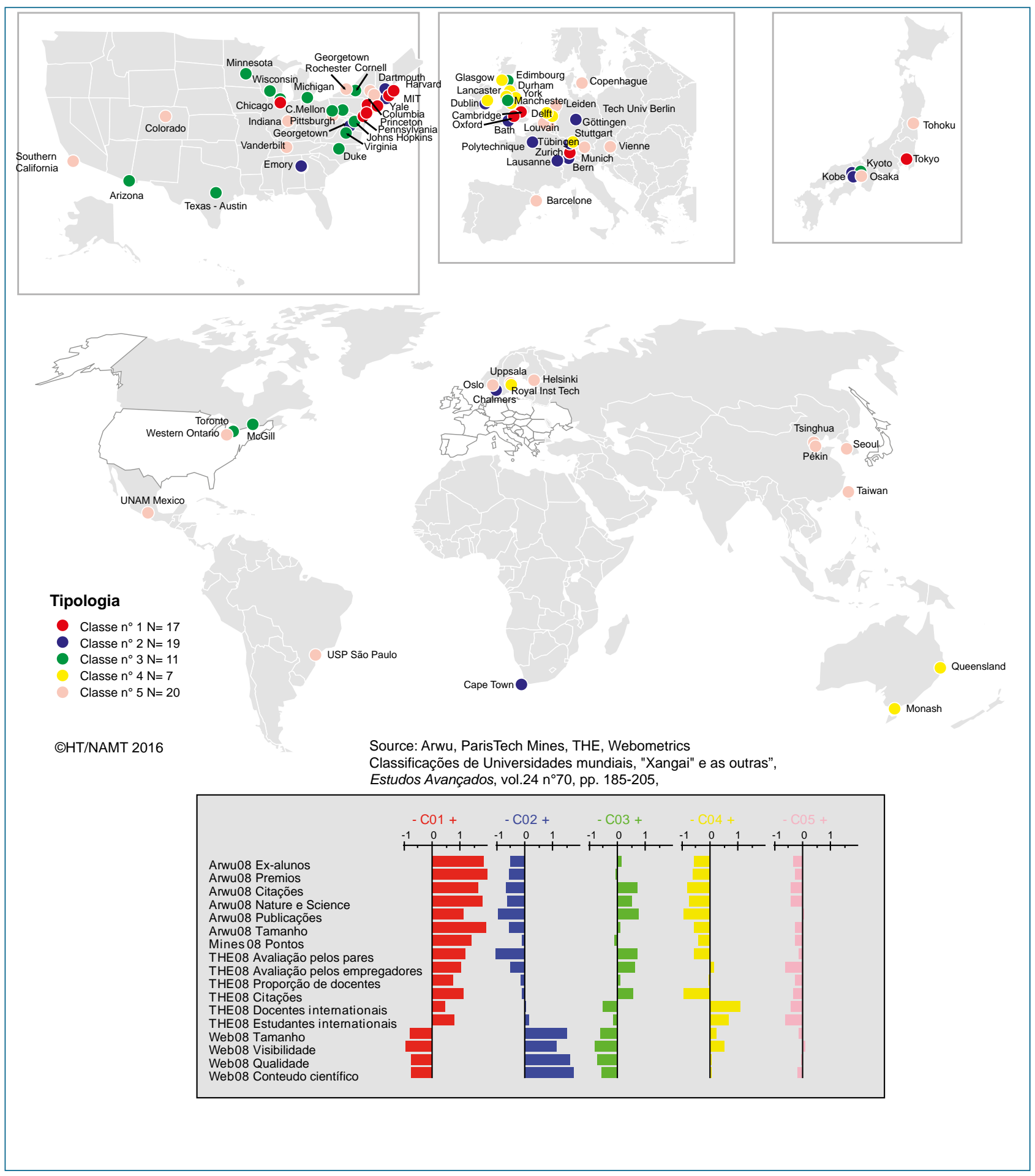

grandes grupos econômicos (Mines ParisTech), a qualidade do ensino (Times Higher Education) e sua presença na Internet (Webometrics).

A análise define cinco grupos: o Grupo 1 reúne as universidades que têm pontuações muito acima da média em todos os critérios (exceto a sua presença na web), o grupo 2 se destaca pela qualidade da sua presença na Web, o grupo 3 por um perfil mais "acadêmico" e desenvolvendo carreiras menos brilhantes - e lucrativas - que o grupo No. 1 . O grupo 4 é o mais aberto para o mundo, com o maior número de estudantes e professores estrangeiros e 
Figura 13. Escolhas dos estudantes

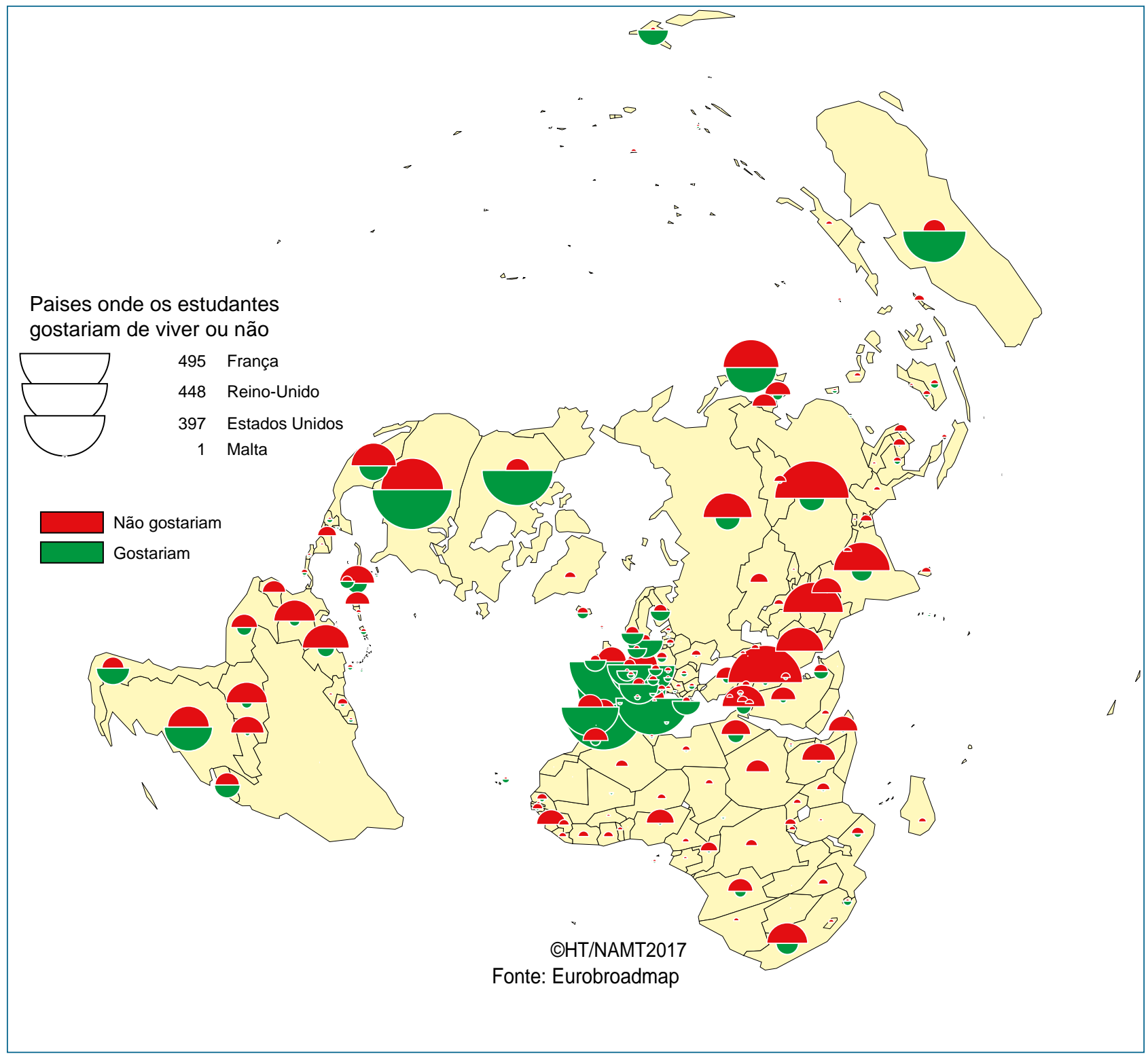

finalmente, o grupo 5 é o mais próximo da média em todas as áreas, reunindo, nesta elite global, países emergentes (China, Brasil, México) e regiões periféricas - do ponto de vista acadêmico - da Europa (Escandinávia, Espanha, Áustria, Bélgica). Este grupo, que contém uma única universidade brasileira, a Universidade de São Paulo (USP), é menos prestigioso que primeiro grupo, tem menos presença na Web do que o segundo, publica menos que o terceiro, é menos internacional do que o quarto, mas está na lista porque é bom em todas estas áreas: já é um bom desempenho, enquanto outros estão ausentes desta lista curta por não se qualificarem em nenhuma dessas áreas, como é o caso de toda a Califórnia, com apenas uma exceção.

Outra maneira de avaliar o lugar do mundo do Brasil no mundo, ainda no contexto acadêmico, é de ver onde os estudantes brasileiros gostaria ou não - de estudar ou morar se fossem escolher outro país. Foi o que fez o projeto de pesquisa Eurobroadmap (<http://www.eurobroadmap. $\mathrm{eu} />$ ). As respostas definiram de novo uma posição intermediaria do Brasil, entre países mais favorecidos, onde os estudantes desejariam ir estudar, e outros onde sequer pensariam em morar, preferindo ficar no Brasil. 
Em geral, os estudantes têm uma preferência pelas regiões mais desenvolvidas, Europa, América do Norte e Austrália. O continente europeu aparece como um lugar cuja imagem é boa entre os alunos, com exceção da rejeição de alguns países onde os estudantes não querem viver, como os países dos Balcãs, a Estônia e a Letônia. O continente norteamericano é outro lugar que os alunos gostam, mas a taxa de recusa dos brasileiros aos EUA é alta, embora o país ainda seja considerado um lugar onde seria possível viver. Outros países das Américas têm imagem positiva, como Chile e Argentina, mas para o último, como os Estados Unidos, aparece uma significativa taxa de rejeição, provavelmente devido à tradicional rivalidade entre Brasil e Argentina.

A Oceania, particularmente a Austrália, é vista como outra área onde os alunos gostariam de viver, principalmente por causa da possibilidade, tendo estudado ali, de se fixar nestes países que têm tradição de imigração. As áreas menos privilegiadas pelos estudantes são alguns países da América do Sul próximo do Brasil (Venezuela, Colômbia, Peru, Equador, Bolívia e Paraguai), os países africanos (África do Sul, Etiópia e Somália) e os do Oriente Médio (Irão, Iraque, Afeganistão e Paquistão) e na Ásia (Índia e China).

\section{Em conclusão, o futebol}

$E$, finalmente, como não evocar o futebol entre os elementos que definem o lugar do Brasil no mundo?

Esse jogo de origem britânica adaptou-se muito bem no Brasil e tornou-se o esporte nacional. Ao cruzar o Atlântico, tornando-se futebol, o football evoluiu bastante em relação ao que praticavam os futuros gentlemen quando eram alunos da escola de Eton. O Brasil passou a ser um dos grandes do futebol, e os seus resultados nos jogos oficiais mostram que figura entre a pequena elite que está sistematicamente presente nas fases finais das competições, ganhando-as frequentemente. Ele tem um saldo positivo com praticamente todos os países do mundo, tanto em jogos ganhos como em gols, com uma única exceção, a Argentina. Será necessário recordar que o Brasil ganhou cinco vezes a Copa do Mundo? A sua quinta vitória ocorreu em 2002, foi o "penta”, ao qual os brasileiros já aspiravam em 1998, quando se frustraram ao não conquistarem o título na memorável final contra a França. As copas de 2006 (ganha pela Itália) e de 2010 (Espanha) foram outras frustrações, mas nada em comparação com a de 2014, quando o Brasil sofreu a humilhante derrota por 7-1 contra a Alemanha.

Ainda é cedo para saber se ou quanto esses resultados vão prejudica-lo, mas até então o Brasil exportava jogadores no mundo inteiro, cerca de mil deles jogam em clubes em 80 países (figura 14). Quem recebeu o maior número deles é o Portugal, por razões linguísticas óbvias, mas outros foram para o Japão, a Coréia e outros países mais exóticos para os brasileiros como a Indonésia, Vietnã, China, Azerbaijão, Finlândia, etc., especialmente porque a maioria dos jogadores são de origem popular e pouco preparados para a vida no exterior.

Deve-se notar que, entre 2004 e 2008 (após esta data as informações não foram mais publicadas), enquanto o seu número diminuía em países vizinhos da América do Sul, na Coreia do Sul e no Japão, houve aumento rápido na África Sul, nos países do Golfo e, especialmente, no Leste europeu, países cujo peso internacional cresceu nestes anos: Mesmo nesta área do esporte é claro que a posição do Brasil na globalização se reforça nas regiões mais ativas do planeta.

Portanto, concluir a análise das fronteiras do Brasil com o futebol faz sentido, já que os brasileiros demostram nos campos de futebol, como na vida real, um gênio da improvisação individual que substitui - quase sempre - as falhas da organização coletiva, e por isso o Brasil é por excelência o país do futebol. Como dizia Millôr Fernandes, poeta, humorista, dramaturgo, desenhista e impenitente produtor de aforismos paradoxais: "Ninguém joga futebol tão bem quanto o brasileiro. Isso porque o futebol e o Brasil são iguaizinhos, não tem lógica”. Apesar de um exagero óbvio - permitido a um humorista - não deixa de ser verdade, os brasileiros tendem a fazer 
Figura 14. Exportações de jogadores de futebol

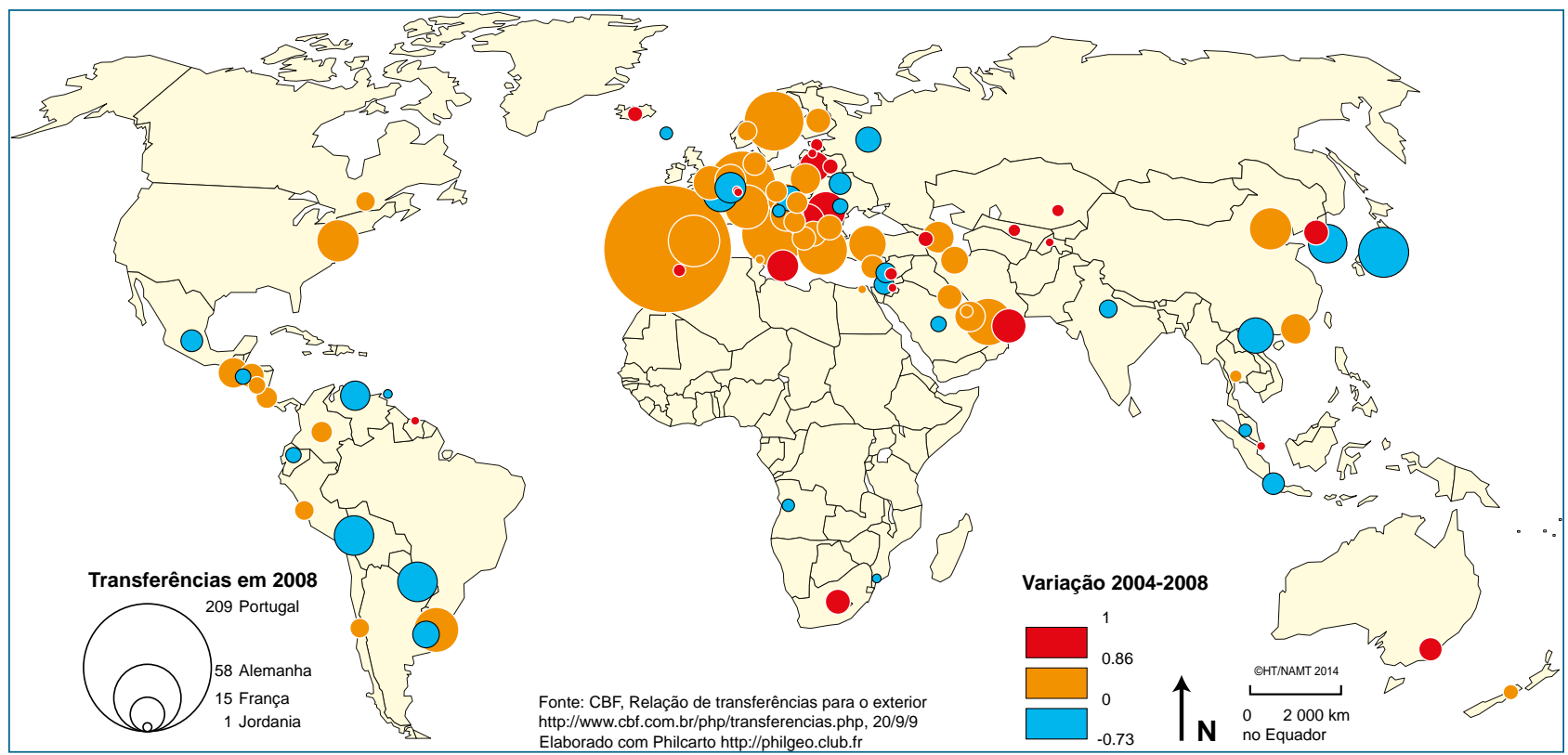

tudo como eles jogam futebol, na improvisação, e geralmente com sucesso. No entanto, este sistema encontrou os seus limites, especialmente na Copa de 2014: quando será que o Brasil vai - na vida como no futebol - se transformar para ultrapassar a sua última fronteira e vir a ser um país realmente e plenamente desenvolvido?

\section{Referências}

De Mello-Théry, Neli Aparecida e Théry, Hervé org. (2013), Visões da Europa, representações e discursos, Neli Aparecida (org.), Annablume, São Paulo.

FIPE, (2012), Caracterização e dimensionamento do turismo doméstico no Brasil - 2010/2011. Relatório executivo, principais resultados selecionados, <http://www. dadosefatos.turismo.gov.br/dadosefatos/demanda turistica/domestica/>.

Piraudeau, Bertrand (2014), Le football brésilien, regards anthropologiques, géographiques et sociologiques, L'Harmattan, Paris.
Secretaria Nacional de Políticas de Turismo, Ministério do Turismo, (2013), Anuário Estatístico de Turismo - 2013, Volume 40, Ano base 2012, <http://www.dadosefatos. turismo.gov.br/dadosefatos/anuario/index.html>.

Théry, Hervé e Mello, Neli Aparecida de, Atlas do Brasil, Disparidades e dinâmicas do território, Edições da Universidade de São Paulo EDUSP, São Paulo 2005 e 2008 <https://www.edusp.com.br/detlivro.asp?id=416880>

Théry, Hervé (2010), "Classificações de Universidades mundiais, "Xangai" e as outras", Estudos Avançados, Issn 0103-4014, vol. 24 no.70, pp. 185-205, doi : 10.1590/ S0103

Théry, Hervé (2014), "Diplomatie, commodities et soft power, la projection mondiale du Brésil", Problèmes d'Amérique latine, n93, ISSN 0765-1333, 2014/3, Dossier: La réélection de Dilma Rousseff: le Brésil en trompe-l'œil, pp. 75-87.

Théry, Hervé (2016), Le Brésil, pays émergé, collection Perspectives géopolitiques, Armand Colin, Paris., $2^{a}$ edição 2016, 280 p.

Théry, Hervé, (2015) Lugares e fluxos do turismo nacional brasileiro,Via@ Tourism review 2015-1(7), <http:// viatourismreview.com/pt/2015/09/art1/>.

\section{Hervé Théry}

Possui graduação em História (1972) e em geografia (1973) pela Université Paris 1 (Panthéon-Sorbonne), mestrado em Geografia pela Université Paris 1 (Panthéon-Sorbonne) (1973), doutorado em Geografia pela Université Paris 1 (PanthéonSorbonne) (1976) e Habilitation à diriger des recherches (Livre docência), pela Université Paris X Nanterre (1994). Atualmente é pesquisador do Centre National de la Recherche Scientifique e professor visitante da USP, Coordenador editorial da revista Confins (http://confins.revues.org, Issn 1958-9212), comitê editorial M@ppemonde (Online) (17697298). Tem experiência na área de Geografia, com ênfase em Geografia Regional, atuando principalmente nos seguintes temas: geografia do Brasil, geografia politica, cartografia tématica, modelização gráfica.

E-mail: Hthery@aol.com 